\title{
Batch spawning decreases competition among early life stages in coastal fishes: a simulation study using red drum Sciaenops ocellatus
}

\author{
Shinnosuke Nakayama ${ }^{1,3, *}$, Kenneth A. Rose ${ }^{2}$, Lee A. Fuiman ${ }^{1}$ \\ ${ }^{1}$ Marine Science Institute, Department of Marine Science, The University of Texas at Austin, 750 Channel View Drive, \\ Port Aransas, Texas 78373, USA \\ ${ }^{2}$ Department of Oceanography and Coastal Sciences, Louisiana State University, \\ 2135 Energy, Coast and Environment Building, Baton Rouge, Louisiana 70803, USA \\ ${ }^{3}$ Present address: Department of Zoology, University of Cambridge, Downing Street, Cambridge CB2 3EJ, UK
}

\begin{abstract}
Batch spawning (reproducing multiple times in a single reproductive season) is mainly considered to be a bet-hedging strategy to cope with environmental uncertainty, but little attention is paid to its consequences for competitive environments of offspring. Here, we investigate how batch-spawning traits can affect recruitment success when offspring experience sizeand density-dependent interference competition. Using an individual-based model, we simulated recruitment of a typical batch-spawning coastal fish in the Gulf of Mexico, where spawning occurs in spatially heterogeneous environments over a single spawning season. We examined the effects of competition intensity among offspring on recruitment success. As offspring were more competitive, higher recruitment was achieved when a population showed batch spawning compared to single spawning. Moreover, interference competition among offspring yielded an increase in total recruitment when the competition intensity was low, suggesting that offspring competition is not always detrimental to recruitment success. Our study proposes a beneficial consequence of a batch-spawning strategy-increasing recruitment by reducing competition among offspring.
\end{abstract}

KEY WORDS: Asymmetric competition $\cdot$ Feeding $\cdot$ Habitat quality $\cdot$ Intraspecific competition

\section{INTRODUCTION}

Fishes and many other taxa commonly reproduce multiple times in a single reproductive season. This so-called 'batch spawning' is mainly viewed as a bethedging strategy in time to cope with uncertain environments for offspring survival (Murphy 1968, Schaffer 1974, Philippi \& Seger 1989, Wilbur \& Rudolf 2006). Parents avoid catastrophic failure and increase the geometric mean of offspring survival by spreading reproductive effort over multiple batches. Batch spawning is usually synchronized in groups because of the benefits of group mating or environmental constraints, resulting in distinct cohorts.
Although batch-spawning traits have evolved mainly as a bet-hedging strategy, batch spawning has consequences for offspring survival in another way; batch spawning alters instantaneous offspring density and size distribution, which is largely responsible for intraspecific competition. Therefore, batchspawning traits could engender significant consequences for offspring survival by altering their competitive environments.

Interference competition often leads to asymmetry in food gain (Persson 1985, Nakayama \& Fuiman 2010) and habitat use (Werner \& Hall 1976, Sutherland \& Parker 1985, Jonsson et al. 2008, Nakayama et al. 2011) among individuals. Interference com- 
petition is density- and size-dependent, and, thus, spawning traits of parents would have a significant influence on interference competition among offspring. Batch spawning would reduce densitydependent competition among offspring, but it would increase asymmetry in competition among offspring when spawning intervals between cohorts are so short that later cohorts arrive in the habitats that older, bigger conspecifics occupy. Therefore, batch-spawning traits inevitably generate intricate competitive relationships among offspring through growth and the influx and efflux of competitors. Consequently, offspring would experience dynamically changing competitive environments over time. However, little is known about how batch-spawning traits of parents would influence competitive environments of offspring and, consequently, recruitment success.

To explore potential consequences of batch spawning for recruitment success under interference competition among offspring, we built an individualbased model for typical batch-spawning fishes in coastal areas. We based the model on red drum Sciaenops ocellatus because red drum is well studied. Red drum occurs in subtropical and temperate coastal areas, and females spawn synchronously 4 to 5 times during fall (Wilson \& Nieland 1994) at about a 2 wk interval (Peters \& McMichael 1987). After 2 to $3 \mathrm{wk}$ of pelagic life when they reach about $7 \mathrm{~mm}$ standard length (SL), larvae are transported into bays by tidal currents (Peters \& McMichael 1987, Brown et al. 2000) and settle into shallow, structured habitats, such as seagrass and oyster beds (Rooker \& Holt 1997). During the settlement period, larvae feed mainly on copepods and mysids (Soto et al. 1998). A wide range of sizes is observed in these larvae simultaneously (between 7 and $25 \mathrm{~mm}$ ) with locally high densities (Rooker et al. 1999), but those bigger than $25 \mathrm{~mm}$ are rarely caught in these habitats because they likely shift to deeper areas (Peters \& McMichael 1987). These situations suggest the possibility of interference competition among settled larvae of different sizes. Earlier studies have shown that red drum larvae exhibit size-dependent aggressive behavior (Nakayama et al. 2009) and experience sizedependent interference competition for food (Nakayama \& Fuiman 2010) and habitat (Nakayama et al. 2011).

We hypothesize that batch-spawning traits influence recruitment success by altering the competitive environment experienced by the offspring. Using an individual-based model, we simulated total recruitment of red drum larvae (approximated as survival to
$25 \mathrm{~mm} \mathrm{SL}$ ) under different batch-spawning traits of a group (i.e. combinations of different spawning intervals and number of spawning events) with varying strengths of interference competition among offspring. We investigated whether batch-spawning traits have significant effects on the competitive environment of early life stages and their recruitment success and how the competition intensity among offspring affects recruitment success under different batch-spawning scenarios. Our model was based on red drum, but a wide range of simulations, including some beyond what is realistic for red drum, were performed to generalize the results to other coastal batch-spawning species, such as spot Leiostomus xanthurus, Atlantic croaker Micropogonias undulates, spotted seatrout Cynoscion nebulosus, and black drum Pogonias cromis.

\section{MATERIALS AND METHODS}

\section{Model description}

We used an individual-based model to simulate the survival of red drum larvae from eggs to $25 \mathrm{~mm}$ in length under different combinations of spawning intervals and number of spawning events (Fig. 1). A fixed annual fecundity for a population was divided equally among a pre-set number of batches, and each batch was released on a pre-set number of days between batches (spawning interval). Eggs released on each day of each batch were followed as individuals. Each individual went through the hourly processes of growth, development, mortality, and movement. Individuals were pelagic until reaching $7 \mathrm{~mm} \mathrm{SL}$, after which they settled onto the 2-dimensional spatial grid, where their growths were determined by the local prey conditions and the presence of other conspecifics in the cell. We called them larvae even after settlement because they are not morphologically fully developed at this size (Fuiman et al. 1998). The spatial grids were classified as open or vegetated, with vegetated cells assigned higher prey densities and lower predation pressures than open cells. Population survival (i.e. recruitment) was calculated as the proportion of survivors $<25 \mathrm{~mm}$ SL to the total number of eggs. The biological information used in the model was based mainly on the traits of red drum in the northern Gulf of Mexico. Model simulations began on August 15 (Day 1) and continued for $170 \mathrm{~d}$, although almost all individuals either died or recruited by about Day 100. 


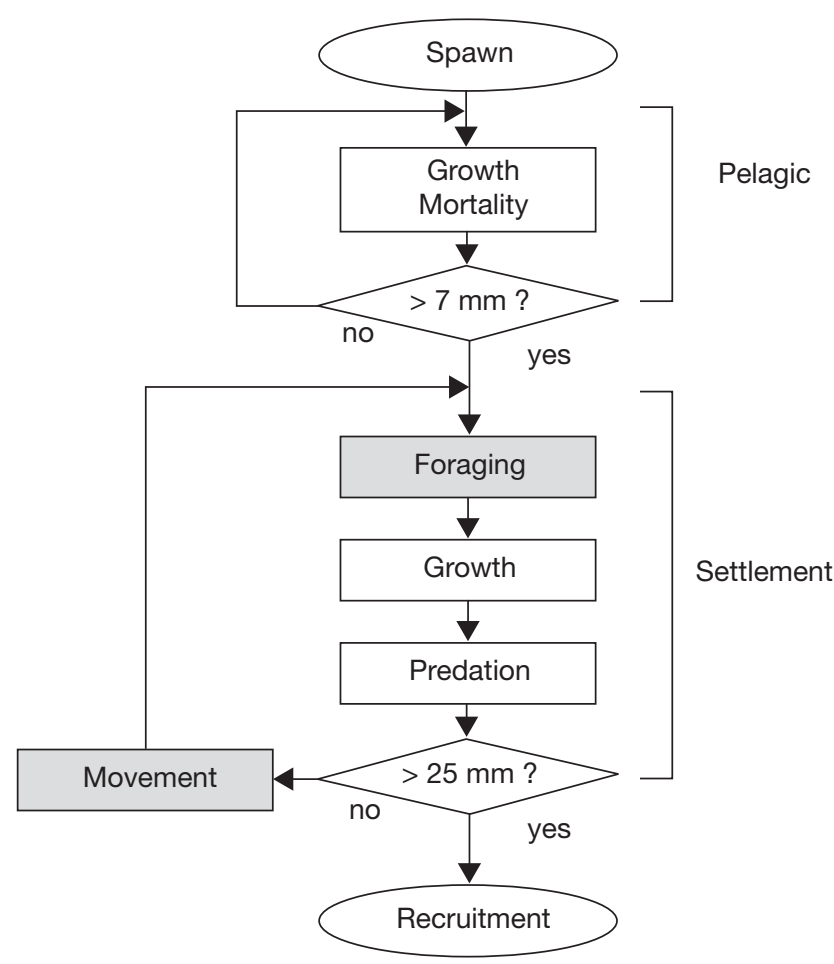

Fig. 1. Sciaenops ocellatus. Overall flow of the individualbased model. During the pelagic period, each individual larva goes through daily growth and mortality processes until it reaches $7 \mathrm{~mm}$ in length. Upon settlement, it goes through spatially specific processes until it reaches $25 \mathrm{~mm}$. Shaded processes (Foraging and Movement) are heavily influenced by batch-spawning traits of females, which alter the intensity of interference competition among larvae

\section{Environment}

The model grid was based on a $1 \mathrm{~km}^{2}$ area selected from a habitat map of Redfish Bay, Texas, USA $\left(27^{\circ} 54^{\prime} 30^{\prime \prime} \mathrm{N}, 97^{\circ} 4^{\prime} 36^{\prime \prime} \mathrm{W}\right)$. Geographical information was obtained from the Texas Parks and Wildlife Department. The selected area was divided into 40000 cells $(200 \times 200$ grids $)$ so that each cell represented $5 \times 5 \mathrm{~m}$ and was assigned to either open water (sandy bottom) or vegetated habitat (Fig. 2). The model grid was composed of $64 \%$ open water and $36 \%$ vegetated habitats. Water depth was set to a constant $30 \mathrm{~cm}$ over all grids, which is a typical depth of water at seagrass beds inhabited by red drum larvae in Redfish Bay (Holt et al. 1983). Water temperature was set equal among cells, and it decreased over the simulation period (Fig. 3). Photoperiod was set at $12 \mathrm{~h}$ light and $12 \mathrm{~h}$ dark.

Each cell contained 2 prey types, calanoid copepods Acartia spp. and mysids Neomysis spp., which are the dominant prey of red drum larvae (Soto et al.

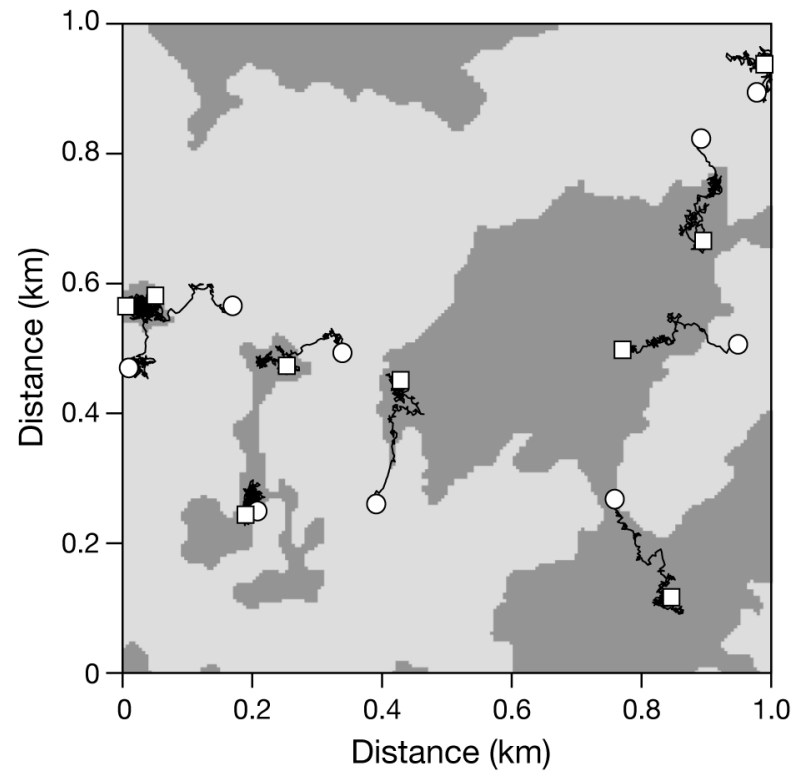

Fig. 2. Sciaenops ocellatus. Habitat map used in the model simulation showing the movements of 10 individuals randomly chosen from the population (spawning interval $=14 \mathrm{~d}$, no. of spawns $=4$, competitive interference quotient $=0$ ). (light grey) open-water habitats, (dark grey) vegetated habitats, (O) starting positions of larvae, ( $\square$ ) ending positions of larval movements

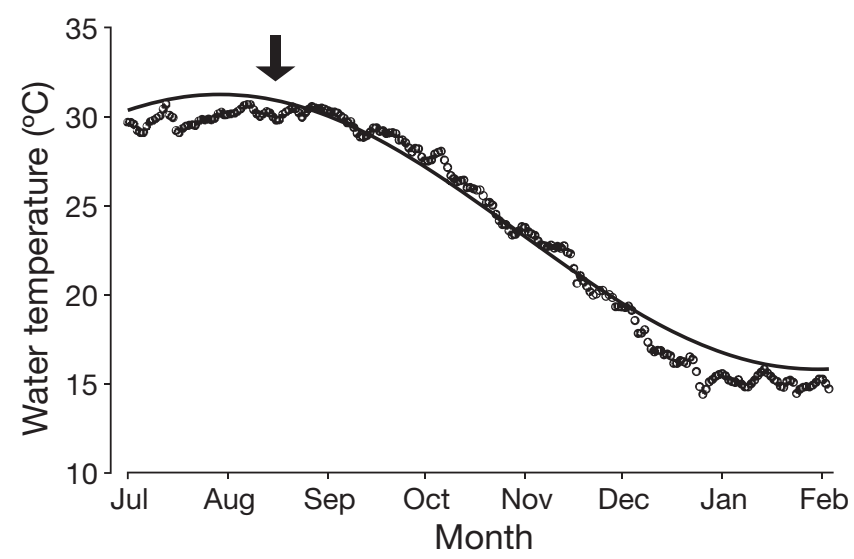

Fig. 3. Sciaenops ocellatus. Water temperature during the spawning season of red drum in Redfish Bay, northern Gulf of Mexico. Points indicate daily average water temperature for $10 \mathrm{yr}$ (1998 to 2007). Line is water temperature ( $T$ ) according to Julian day $(D)$ used in the simulation following $T=$ $23.53-3.27 \sin (0.017 D)-6.99 \cos (0.017 D)$

1998). In each cell, the density of each prey type (ind. $\mathrm{ml}^{-1}$ ) was updated hourly based on a logistic growth model. For simplicity, we did not include mixing of prey among cells. A maximum population growth rate for copepods $\left(r_{0}, \mathrm{~d}^{-1}\right)$ was computed as $r_{0}=$ $0.0455 \mathrm{e}^{0.111 T}$, where $T$ is water temperature $\left({ }^{\circ} \mathrm{C}\right)$ (Huntley \& Lopez 1992), and a maximum population 
growth rate of mysids was set to $0.5 r_{0}$. The carrying capacities $(K)$ for copepods and mysids were based on densities observed in vegetated habitats and the adjacent open water in Aransas Bay, Texas $\left(27^{\circ} 57^{\prime} 23^{\prime \prime} \mathrm{N}, 96^{\circ} 59^{\prime} 21^{\prime \prime} \mathrm{W}\right)$ on October 10 and November 19, 2008 (S. Nakayama unpubl. data). The carrying capacity of mysids was set higher in vegetated habitats $\left(5.0 \times 10^{-4}\right.$ ind. $\left.\mathrm{ml}^{-1}\right)$ than in open water $\left(0.8 \times 10^{-4}\right.$ ind. $\left.\mathrm{ml}^{-1}\right)$, but the carrying capacity of copepods was set at equal levels in vegetated habitats and open water $\left(1.2 \times 10^{-2}\right.$ ind. $\left.\mathrm{ml}^{-1}\right)$. Prey densities in each cell were updated hourly by first subtracting the consumption by red drum larvae in the cell and then adding the increase from the population growth rate.

\section{Spawning traits}

The model assumed that the annual fecundity of a population was equally divided over the spawning events and released synchronously (Wilson \& Nieland 1994), with each spawning event continuing over 4 consecutive days (S. Nakayama pers. obs. of captive spawners). Also, the model assumed that mortality and physiological changes of females was negligible during the reproductive season. The number of eggs for 1 spawning event was divided into 4 subsets, and each subset of eggs was released over 4 consecutive days. We set annual fecundity of the population at 160 million eggs to generate larval densities comparable to a reported density ( 0.7 ind. $\mathrm{m}^{-2}$ for larvae 4 to $30 \mathrm{~mm} \mathrm{SL}$; Rooker \& Holt 1997). The initial spawning date of red drum (Day 1 ) was set to be August 15, which is typical for red drum in the Gulf of Mexico (Wilson \& Nieland 1994).

\section{Pelagic period}

Survival and growth of each individual was followed hourly. Instead of tracking all individuals, we used a super-individual approach, in which each super-individual represented multiple identical individuals (Scheffer et al. 1995). We followed 15000 super-individuals, so each super-individual was initially assigned a worth $(S)$ of 10667 individuals (15 000 super-individuals represent 160 million eggs). The number of batches and the spawning interval determined how the 15000 super-individuals were introduced into simulations. For example, a simulation with 4 batches and $14 \mathrm{~d}$ intervals introduced 625 super-individuals (each worth 10667 eggs) on
Days 1-4, 15-18, 29-32 and 43-46 (16 d in total). The worth of the super-individual was reduced hourly proportionally to mortality. We eliminated a superindividual from the model when its worth became less than 0.001 because at that level it had virtually no effect on the growth and habitat use of other individuals. Additional model simulations with increasing numbers of super-individuals showed that 15000 individuals generated results that were insensitive to the number of super-individuals followed.

Eggs took $21 \mathrm{~h}$ to hatch (S. Nakayama pers. obs.), and at hatching each super-individual was assigned an initial length of $2.06 \mathrm{~mm}$ and a dry weight of $31.27 \mu \mathrm{g}$ (S. Nakayama pers. obs.). The daily growth rate increased with temperature as: $G=-0.0007 T^{3}+$ $0.0372 T^{2}-0.1953 T-0.2202$, where $G$ is a percent daily increase of length and $T$ is water temperature $\left({ }^{\circ} \mathrm{C}\right)$ (Pérez-Domínguez et al. 2006). After hatching, growth rate was randomly assigned hourly to each super-individual from a normal distribution with a mean of $G$ and a standard deviation of $0.4 G$ (derived from Pérez-Domínguez et al. 2006). Length was incremented by $0.01 \mathrm{G} / 24$ each hour. As the simulation progressed, individuals took longer to reach settlement size because of the seasonally decreasing temperature (Fig. 3). Eggs and pelagic larvae experienced an instantaneous daily mortality rate of 0.27 as a combination of predation, starvation and advection (Levin \& Stunz 2005), which decreased the worth of each super-individual hourly as $S_{t+1}=S_{t} \mathrm{e}^{-0.27 / 24}$ in the model, where $\mathrm{S}_{t}$ denotes a worth of a superindividual at hour $t$.

\section{Settlement period with competition}

Upon reaching $7 \mathrm{~mm} \mathrm{SL}$, each super-individual entered the settlement period and was placed in a randomly selected cell on the settlement area. Prey encounter rates during the settlement period were determined by the size-dependent search rate $a$ $\left(\mathrm{ml} \mathrm{s}^{-1}\right)$ and prey handling time $h(\mathrm{~s})$. Search rate and handling time were measured in a laboratory experiment using Holling's Type II functional response (Supplement 1 at www.int-res.com/articles/ suppl/m441p213_supp.pdf).

We used van der Meer's model (1997) to include asymmetric interference competition in feeding. This is an extension of Beddington's (1975) model, which incorporated the interference competition into Holling's Type II functional response function:

$$
E=\frac{a N}{1+a h N+q p}
$$


where $E$ is prey encounter rate (prey s${ }^{-1}$ ), $N$ is prey density (ind. $\mathrm{ml}^{-1}$ ), $q$ is the interference coefficient (s competitor ${ }^{-1}, q \geq 0$ ), and $p$ is the number of competitors co-located with the individual. The interference coefficient $(q)$ can be interpreted as the time spent for interference during prey search per unit time. Beddington's model decreases prey encounter rate of an individual as the number of competitors $(p)$ increases, and it becomes equivalent to Holling's equation when there is no interference among competitors $(q=0)$. This equation, however, treats all competitors as being equally competitive, which is not appropriate for red drum larvae because their interference competition is size-dependent (Nakayama \& Fuiman 2010).

To include asymmetry in competition among individuals, van der Meer (1997) proposed to replace $p$ in Beddington's (1975) model with the effective competitor unit $\left(v_{j k}\right)$. The effective competitor unit is the relative competitive weight of competitor $k$ on individual $j$. We approximated $v_{j k}$ from Nakayama \& Fuiman (2010) as:

$$
V_{j k}=1-\frac{0.24 \Delta L}{0.31+0.46 \bar{L}}
$$

where $\bar{L}$ is the mean length of individuals $j$ and $k$ and $\Delta L$ is the difference in length $(j-k)$. The effective competitor unit becomes $>1$ when competitor $k$ is bigger than individual $j$ and $<1$ when the competitor $k$ is smaller than individual $j$ (Fig. 4).

The effective competitor unit was scaled by the worth of each competitor, and the prey encounter rate of an individual $\left(E^{\prime}\right)$ was computed hourly by summing the effective competitor units of all competitors within a $5 \mathrm{~m}$ radius:

$$
E^{\prime}=\frac{a N}{1+a h N+q \Sigma_{k=1}^{p} V_{j k}}
$$

An individual was determined to feed on copepods, mysids, or both, depending on the profitability of these prey types, which was computed from caloric values of prey, prey encounter rate, prey capture success, and handling time (Letcher et al. 1996). Details of prey selection are found in Supplement 2 at www.int-res.com/articles/suppl/m441 p213_supp.pdf. Once the prey types in the diet were determined, hourly prey consumption was calculated for each individual. Individuals were allowed to forage either until their consumption exceeded the daily maximum prey consumption or up to $12 \mathrm{~h}$ of light each day. Prey consumption was scaled by

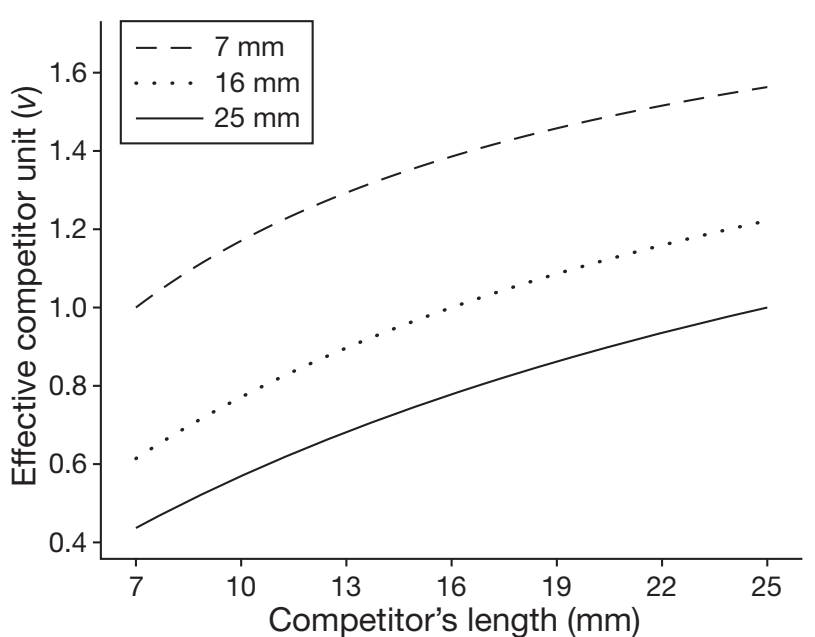

Fig. 4. Sciaenops ocellatus. Relationship between competitor's length $(\mathrm{mm})$ and effective competitor unit $(\mathrm{v})$ for individual larvae of different sizes (see Eq. 2). Effective competitor units were included in the model to account for sizedependent interference competition (see Eq. 3). Line styles indicate 3 different standard lengths of focal fish used

the worth of an individual when it was subtracted from the prey density in the cell.

\section{Growth and starvation mortality during settlement period}

During the settlement period, hourly growth was calculated using an energy budget approach (Supplement 3 at www.int-res.com/articles/suppl/m441 p213_supp.pdf). Net energy gain ( $\mathrm{cal} \mathrm{h}^{-1}$ ) was calculated by multiplying consumption rate by assimilation efficiency and then by subtracting metabolism (resting, active, and specific dynamic action) and excretion. Calories gained or lost were converted to dry weight $(\mu \mathrm{g})$ at $0.004 \mu \mathrm{g} \mathrm{cal}^{-1}$ (Fontaine et al. 2007), and weight of the larva was updated each hour. Since larvae were only to feed during the $12 \mathrm{~h}$ light period, all individuals lost weight during the $12 \mathrm{~h}$ dark period.

The weight and length of a larva were coupled so that length increased only when weight exceeded the weight expected from the current length. The new length was calculated from a relationship between dry weight $(W, \mu g)$ and length $(L, \mathrm{~mm})$ that was obtained from laboratory-reared red drum as: $W=3.590 L^{2.995}$ (5.5 to $27.3 \mathrm{~mm} \mathrm{SL}, \mathrm{n}=240$; $\mathrm{S}$. Nakayama unpubl. data). Larvae were assigned to die from starvation when their weight became $75 \%$ of their maximum past weight. 


\section{Predation mortality}

During the settlement period, predation mortality of red drum was dependent on the length of larvae and habitat type. Predators were typified by pinfish Lagodon rhomboides, which are voracious predators of red drum (Fuiman 1994) and very abundant in Gulf of Mexico estuarine environments including the modeled area (Rooker et al. 1998). Predation mortality rate in open water $\left(Z_{\text {open, }} \mathrm{m}^{-2}\right.$ predator $\left.{ }^{-1} \mathrm{~h}^{-1}\right)$ was set higher than that in seagrass habitats $\left(Z_{\text {veg }}\right.$, $\mathrm{m}^{-2}$ predator $^{-1} \mathrm{~h}^{-1}$ ) and decreased as larvae became larger (modified from Rooker et al. 1998):

$$
\left\{\begin{array}{l}
Z_{\text {open }}=0.48(-0.103 \cdot \ln L+0.508) \\
Z_{\text {veg }}=0.48(-0.146 \cdot \ln L+0.491)
\end{array}\right.
$$

Predation mortality decreased the worth of each super-individual hourly as $S_{t+1}=S_{t} \mathrm{e}^{-z}$. Predator density was set uniformly at 0.25 ind. $\mathrm{m}^{-3}$ in all cells, which produced realistic recruitment success under typical spawning traits of red drum (4 times at $14 \mathrm{~d}$ intervals; Peters \& McMichael 1987). Even though some evidence exists that pinfish are concentrated in vegetated habitats (Jordan et al. 1996), we assumed a uniform distribution for predator density because the data were insufficient to quantify density differences within the fine-scale habitat map of the model. Simulated survival from settlement $(7 \mathrm{~mm}$ SL) to recruitment (25 mm SL) was $4.0 \%(q=0)$ and $2.1 \%(q=10)$.

\section{Movement}

Locations of all individuals were recorded in continuous space (distance in meters in the horizontal and vertical from the lower left corner in Fig. 2), which was used to determine the cell inhabited by the individual. During each hour of the $12 \mathrm{~h}$ of light, settled individuals were assigned to evaluate the neighboring cells and moved towards the cell with the highest habitat quality. Habitat quality of each neighboring cell $(Q)$ was approximated by the ratio of the expected energy gain $(\Delta C)$ to the expected mortality rate $(Z)$ in the next hour (Gilliam \& Fraser 1987 , Houston et al. 1993):

$$
Q=\frac{\Delta C}{Z}
$$

The prey densities and the competitors in the neighboring cells determined the expected prey consumption of the individual in the next hour (Supplement 3). An individual moved $5 \mathrm{~m}$ hourly (approxi- mated from Bushon et al. 2007) to the center of the cell that had the maximum habitat quality within $30 \mathrm{~m}$ of its present location, assuming that fish could detect environmental gradients from local cues. We used a larger neighborhood than fish could actually travel in $1 \mathrm{~h}$ to approximate growth and predation gradients; our model did not represent variation in space on the meter spatial scales sufficiently well enough to use a $5 \mathrm{~m}$ search neighborhood. To create reasonable movements, an individual estimated habitat qualities of all cells within $30 \mathrm{~m}$ of its present location. Larvae were not allowed to move beyond the edge of the map. Individuals were not allowed to move during the dark period of the day.

\section{Simulation experiments}

The number of total recruits (i.e. survivors to $25 \mathrm{~mm}$ SL) was simulated under different spawning traits and different competition intensities. We used 6 values for the number of batches spawned per season $(1,2,3,4,5,6$ batches), 4 values for spawning interval $(4,7,14,21 \mathrm{~d})$, and 9 values of competition intensity $(q=0,0.003,0.01,0.03,0.1,0.3,1,3,10)$. We used these simulations to explore the optimal spawning traits that maximized recruitment when larvae experience interference competition. We expressed recruitment as \% survival [i.e. (total recruits / total eggs) $\times 100]$.

We explored the recruitment for all simulations and detailed results for 2 of the simulations. The detailed results show when larvae experience no interference competition $(q=0)$ and strong interference competition ( $q=10)$, with a spawning trait of 4 batches at $14 \mathrm{~d}$ intervals, which is commonly observed in nature (Peters \& McMichael 1987). From these detailed results we determined larval densities over time and the lengths and worths of 10 randomly selected super-individuals from each day of spawning. All simulations were presented as surface plots of recruitment versus spawning intervals and number of spawning events. For a subset of the simulations (1, 3 and 5 batches), we also plotted recruitment against $q$.

We calibrated the model by varying predator density until we obtained realistic survival under typical spawning traits (4 batches at $14 \mathrm{~d}$ intervals). Therefore, all comparisons in this analysis are relative to this baseline; model-generated results (e.g. recruitment) for a specific set of spawning traits are not meant to be interpreted as absolute values expected to be observed in the field. 


\section{RESULTS}

When eggs were released in 4 batches at $14 \mathrm{~d}$ intervals with no interference competition $(q=0)$, individuals moved about 200 to $300 \mathrm{~m}$ after settlement and spent about 75 to $85 \%$ of their time in vegetated habitats (Fig. 2), which was typical for all other simulations. Because most fish stayed in vegetated habitats once they found them, residence time in vegetated habitats negatively reflected the transition time that individuals needed to find vegetated habitats. However, strong interference competition resulted in slower growth, lower survival, and lower recruitment compared to no interference competition under the same spawning scenario (Fig. 5). Densities over time appeared similar between $q=0$ and $q=10$ simulations (Fig. 5a,b), but strong interference competition resulted in longer duration of the settlement period (Fig. 5c,d) and higher mortality compared to no interference competition (Fig. 5e,f). Median worth of superindividuals at recruitment was 83.3 individuals for $q=0$ and 6.0 individuals for $q=10$, and duration of settlement period was $16.1 \mathrm{~d}$ and $19.0 \mathrm{~d}$, respectively. Slowed growth in the both pelagic and set-
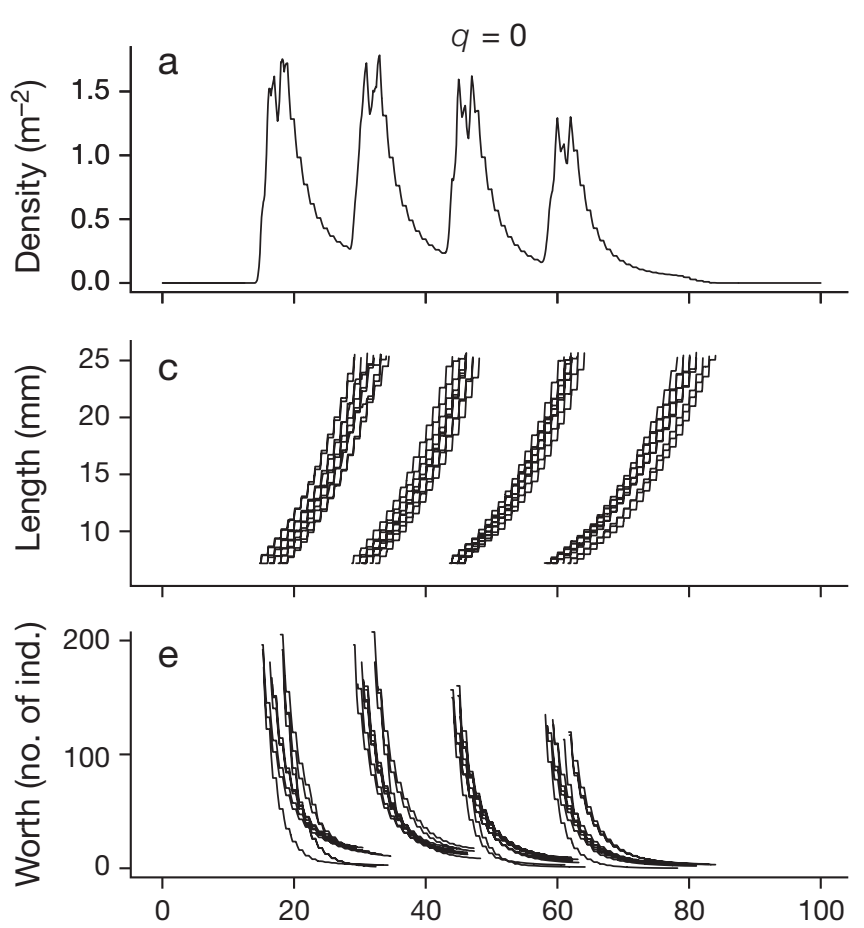

Time since first spawning (d) tled phases resulted in higher cumulative mortality; there was little starvation mortality in simulations. As a result, recruitment decreased drastically with strong interference competition $(0.071 \%$ for $q=0$, $0.036 \%$ for $q=10$ ).

Batch spawning yielded higher recruitment when larvae experienced interference competition (Fig. 6). In the absence of interference competition among settled larvae $(q=0)$, maximum recruitment was attained when females spawned their entire annual fecundity at once, and recruitment declined monotonically as the number of spawning events or the spawning interval increased (Fig. 6a). As larvae experienced interference competition $(q>0)$, recruitment showed a convex relationship with number of batches and spawning interval. Maximum recruitment occurred at spawning 3 times at $14 \mathrm{~d}$ intervals for $q=0.1$ (Fig. 6b), spawning 4 times at $14 \mathrm{~d}$ intervals for $q=1$ (Fig. $6 \mathrm{c}$ ), and spawning 5 times at $14 \mathrm{~d}$ intervals for $q=10$ (Fig. 6d). These spawning traits resulted in median durations of the settlement period of 15.6, 18.1 and $19.1 \mathrm{~d}$, respectively. For all simulations, median durations of the settlement period ranged from $14.2 \mathrm{~d}$ (1 batch, $q=0.01)$ to $21.5 \mathrm{~d}$ (1 batch, $q=10$ ).
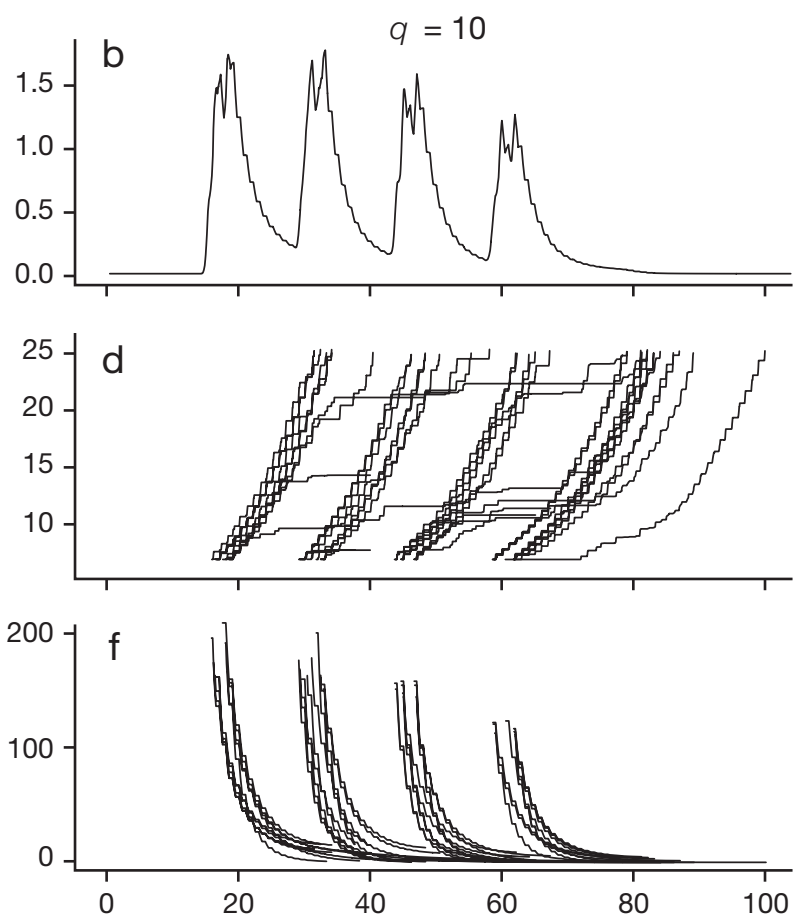

Fig. 5. Sciaenops ocellatus. Detailed model results for 2 examples that contrast no competition $\left(\mathrm{a}, \mathrm{c}, \mathrm{e}_{;} q=0\right)$ with strong competition (b,d,f; $q=10)$ when females spawned 4 batches at 14 d intervals. $(\mathrm{a}, \mathrm{b})$ Larval density over time since the first spawning event (days, d). (c,d) Lengths of 10 representative super-individuals randomly chosen from each spawning day. (e,f) The number of individuals represented by each super-individual (worth) of the same randomly selected 10 super-individuals over time 

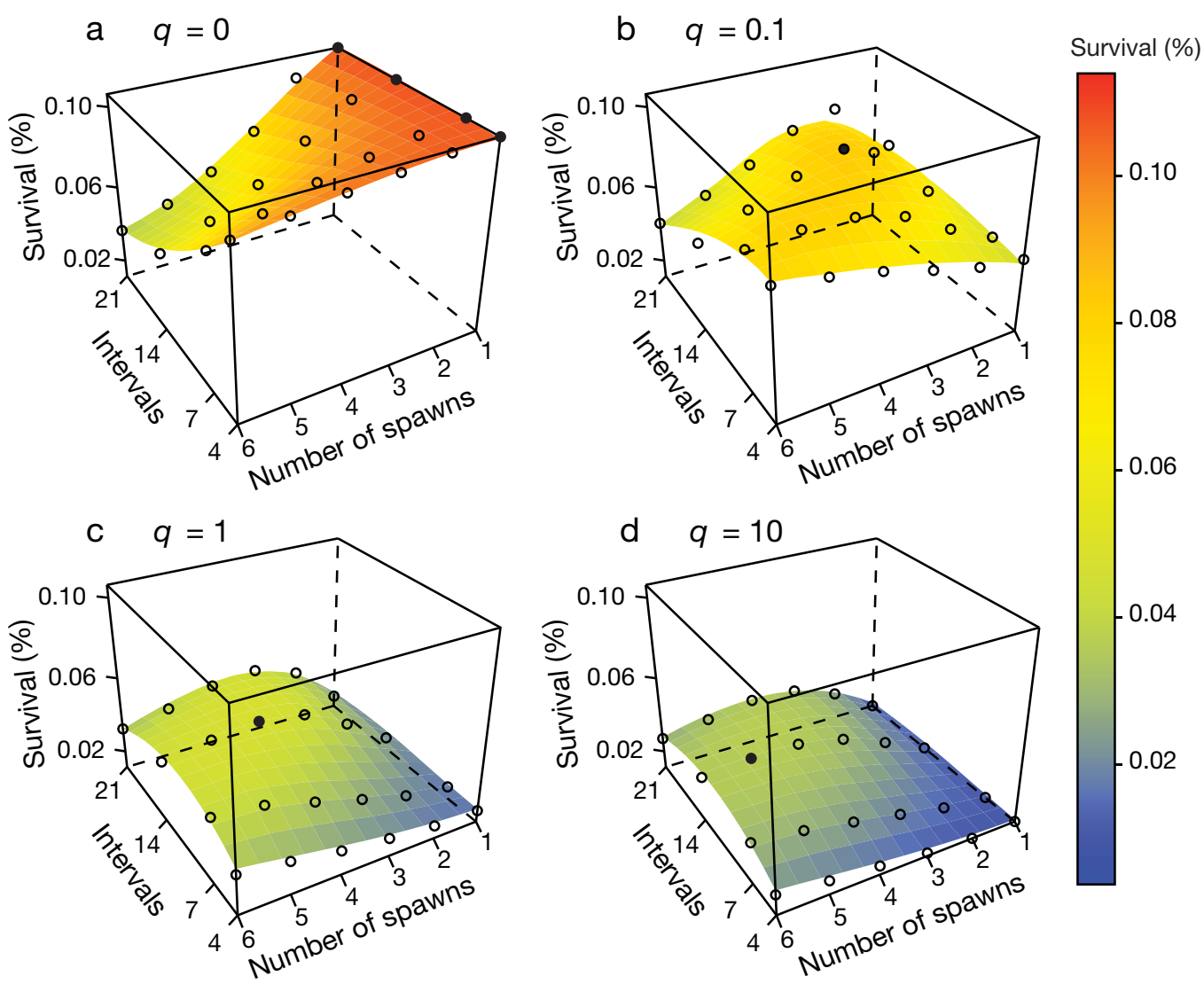

Fig. 6. Sciaenops ocellatus. Recruitment (percent survival from egg to $25 \mathrm{~mm}$ standard length) for all combinations of number of batches and spawning intervals for different levels of competitive interference: (a) $q=0$, (b) $q=0.1$, (c) $q=1$, (d) $q=10$. o: actual value of recruitment; $\bullet$ : maximum value. The smooth surface was obtained using a LOWESS function. The color key on the right indicates the value of recruitment

When eggs were spawned every day (i.e. spawning at $4 \mathrm{~d}$ intervals because each batch was released over 4 consecutive d), recruitment declined as larvae experienced stronger interference competition (Fig. 7a). However, at 7, 14, and 21 d intervals, recruitment increased when larvae experienced interference competition at relatively low intensity $(0.1 \leq q \leq 1$; Fig. $7 \mathrm{~b}$ to $\mathrm{d})$. Interference competition had less influence on recruitment as the number of spawning events or the spawning interval increased.

\section{DISCUSSION}

Our study proposes a beneficial consequence of batch spawning; it can reduce the realized strength of interference competition among early life stages and increase their survival. In the simulations, batch spawning had a negative effect on larval survival when larvae were intrinsically non-competitive $(q=$ 0 ), whereas batch spawning increased larval survival when larvae were competitive. In the northern Gulf of Mexico, red drum spawn synchronously in groups 4 to 5 times per season at about $2 \mathrm{wk}$ intervals (Peters \& McMichael 1987). Likewise, prolonged reproduction is often seen in many species that use estuarine habitats during early life stages, such as spot (FloresCoto \& Warlen 1993), Atlantic croaker (Barbieri et al. 1994), spotted seatrout and black drum (Saucier $\&$ Baltz 1993). Considering the ubiquity of interference competition in animals, prolonged reproduction would have beneficial consequences on offspring survival by using time as a niche axis, especially where competition plays a critical role in their survival.

In the simulations run here, maximum recruitment $(0.106 \%)$ was attained when females released all eggs at once at the beginning of the reproductive season with no competition among larvae $(q=0)$. However, batch spawning increased recruitment success as larvae became more competitive to increase their own survival (i.e. an increase in $q$ ). In multiplebreeding birds, competition among offspring for parental care selects the wider reproductive interval 


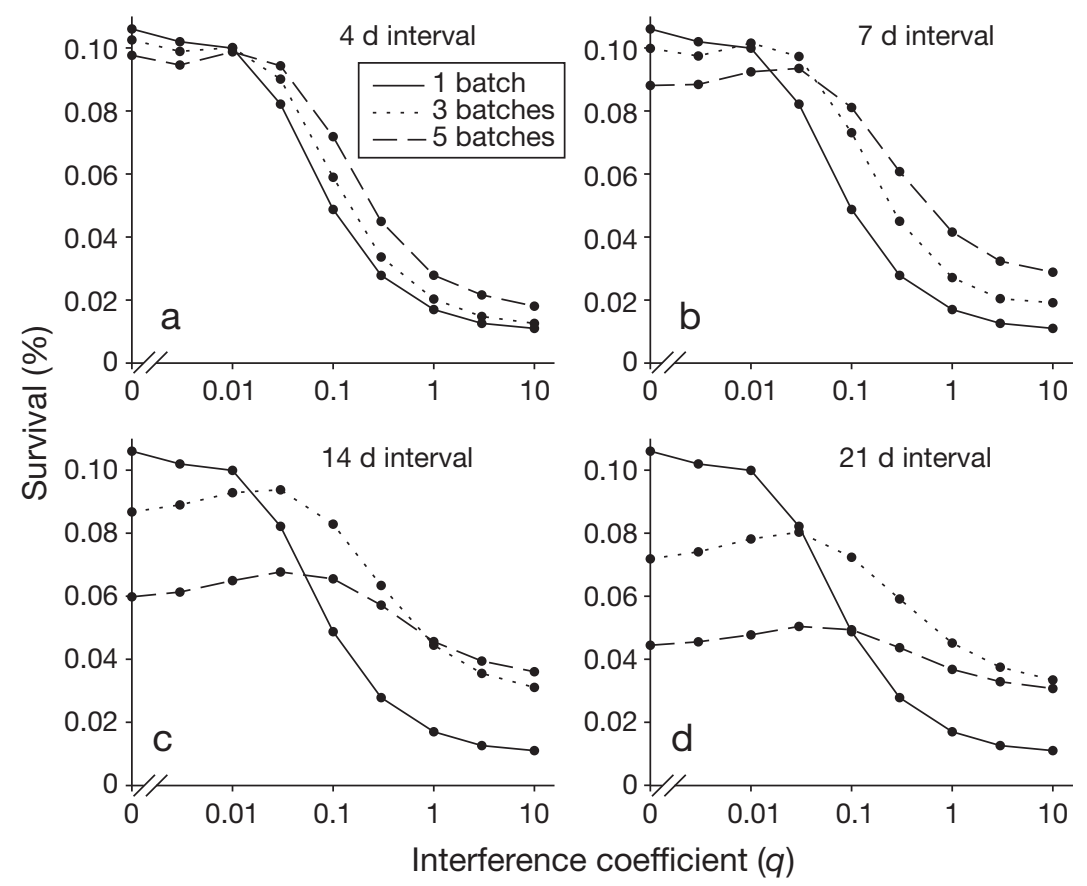

Fig. 7. Sciaenops ocellatus. Relationship between recruitment and the interference competition coefficient $(q)$ for 3 levels of batches $(1,3,5)$ for spawning at intervals of (a) $4 \mathrm{~d}$, (b) $7 \mathrm{~d}$, (c) $14 \mathrm{~d}$, and (d) $21 \mathrm{~d}$. The interference coefficient is shown on a logarithmic scale

to reduce temporal overlap between clutches (Milinski et al. 1995, Verhulst et al. 1997, Grüebler \& MaefDaenzer 2008). Although batch spawning is considered mainly as a bet-hedging strategy in broadcast spawners, it also has the beneficial consequence of reducing interference competition among early life stages. A wider spawning interval would be more beneficial to reducing intra-cohort competition, which leads each cohort to grow slower and stay longer in the nursery habitats. A wider spawning interval would also allow prey populations to recover when they are heavily exploited, but an unnecessarily wide interval may create temporal pockets of unused niches. Therefore, spawning groups would find the greatest benefit (increased recruitment success) when spawning events take place around the optimal time of the reproductive season, while separating the events enough to reduce inter-cohort competition.

Our results suggest that interference competition among larvae was not necessarily detrimental to recruitment success. For most of the combinations of spawning traits simulated, interference competition increased total recruitment when competition was not strong (consistent humps in recruitment for $q=$ 0.01 to 0.1 ; Fig. 6). This increase comes from a skewed frequency distribution of individual growth rate; asymmetric competition decreases feeding rates of the smaller individuals to a greater extent than those of the larger individuals, and as a consequence, the larger individuals experience increased prey availability, enough to offset the decrease in their feeding rates through interference competition. Total survival increases by reducing growth of a subset of offspring and enhancing growth of the rest. The apparent waste of reproductive effort would arise from selection on each spawner to maximize its fitness (Sibly 1983). In Arctic char Salvelinus alpinus, size differences among individuals within the population are contracted when prey density is low (Byström \& Andersson 2005). This is because the advantages for the larger individuals through asymmetric exploitative competition cannot keep up with the increasing metabolic demands for growth. Therefore, the positive effect of interference competition in our simulations may not be observed when prey density is lower than the level that we used in our simulation.

Spawning at $4 \mathrm{~d}$ intervals is equivalent to asynchronous spawning of breeders in a population because eggs enter the system daily (each batch was released over 4 consecutive $d$ in the model). Recruitment was lower when eggs were released in the system daily than when spawned synchronously at certain intervals, suggesting an advantage for reproductive synchrony. Reproductive synchrony is known to be an adaptive strategy for predator swamping, resource matching, and increasing fertilization rates in broadcast spawners (Ims 1990, Kelly 1994). Our results suggest that reproductive synchrony when combined with batch spawning can also be advantageous by increasing offspring survival at the population level when in the presence of interference competition. Temporally separating reproduction can decrease the density of older cohorts through mortality and emigration, which would lessen negative effects of asymmetric competition on new cohorts.

Synchronous batch spawning in groups is also attainable if subgroups of parents spawn at different times of the season. Various selection pressures, such as environmental uncertainty (Schaffer 1974, Brommer et al. 2000, Wilbur \& Rudolf 2006), age structure in a population and age-specific fecundity (Orzack \& Tuljapurkar 1989, Benton \& Grant 1999), and physiological constraints on reproduction (Partridge \& Sibly 
1991, Ricklefs \& Wikelski 2002, Elkin \& Reid 2005) would act on individual spawning strategies. For example, in migratory birds inferior parents breed later, waiting for superior competitors to finish using the breeding sites (Kokko 1999). Also, first-time breeders often experience higher costs for reproduction and lower success (Curio 1983, Cam \& Monnat 2000). Thus, although batch spawning in groups can have a beneficial consequence for recruitment success, selection on spawning traits of each individual may act in the opposite direction.

Our model and analysis are exploratory in nature. There are many uncertainties in the formulations and parameter values used in the model, and we made many simplifying assumptions about spatial heterogeneity, prey dynamics, and predation mortality. However, we used some critical information from a laboratory experiment specifically designed to quantify the effects of competition in the functional response relationship (Nakayama \& Fuiman 2010). Also, many of our formulations of habitat, growth, mortality, and movement have been used in other models or have their roots in previous experiments or analyses, and while they are uncertain, they appear to be reasonable approximations. Thus, while our analysis is exploratory, our interpretation of the results would be applicable to a wide range of batch spawning species that utilize limited areas during early life stages and deserves further investigation with additional modeling, laboratory experiments, and field data collection.

Acknowledgements. We thank G. Joan Holt and the staff of the Fisheries and Mariculture Laboratory at the University of Texas Marine Science Institute, who generously provided red drum eggs. We also thank A. F. Ojanguren, K. Madden, C. Foster, S. Mohanty and L. Havel for many suggestions and discussions. S.N. was financially supported by an E. J. Lund Fellowship from the University of Texas Marine Science Institute and by a grant from the National Science Foundation (OCE-0425241) to L.A.F.

\section{LITERATURE CITED}

Barbieri LR, Chittenden ME Jr, Lowerre-Barbieri SK (1994) Maturity, spawning, and ovarian cycle of Atlantic croaker, Micropogonias undulatus, in the Chesapeake Bay and adjacent coastal waters. Fish Bull 92:671-685

Beddington JR (1975) Mutual interference between parasites or predators and its effect on searching efficiency. J Anim Ecol 44:331-340

Benton TG, Grant A (1999) Optimal reproductive effort in stochastic, density-dependent environments. Evolution 53:677-688

Brommer J, Kokko H, Pietiäinen H (2000) Reproductive effort and reproductive values in periodic environments.
Am Nat 155:454-472

Brown CA, Jackson GA, Brooks DA (2000) Particle transport through a narrow tidal inlet due to tidal forcing and implications for larval transport. J Geophys Res 105: 24141-24156

Bushon AM, Stunz GW, Reese MM (2007) Evaluation of visible implant elastomer for marking juvenile red drum. N Am J Fish Manage 27:460-464

Byström P, Andersson J (2005) Size-dependent foraging capacities and intercohort competition in an ontogenetic omnivore (Arctic char). Oikos 110:523-536

Cam E, Monnat JY (2000) Apparent inferiority of first-time breeders in the kittiwake: the role of heterogeneity among age classes. J Anim Ecol 69:380-394

Curio E (1983) Why do young birds reproduce less well? Ibis 125:400-404

Elkin CM, Reid ML (2005) Low energy reserves and energy allocation decisions affect reproduction by mountain pine beetles, Dendroctonus ponderosae. Funct Ecol 19: 102-109

Flores-Coto C, Warlen SM (1993) Spawning time, growth, and recruitment of larval spot Leiostomus xanthurus into a North Carolina estuary. Fish Bull 91:8-22

Fontaine LP, Whiteman KW, Li P, Burr GS and others (2007) Effects of temperature and feed energy on the performance of juvenile red drum. Trans Am Fish Soc 136: 1193-1205

Fuiman LA (1994) The interplay of ontogeny and scaling in the interactions of fish larvae and their predators. J Fish Biol 45:55-79

Fuiman LA, Poling KR, Higgs DM (1998) Quantifying developmental progress for comparative studies of larval fishes. Copeia 1998:602-611

Gilliam JF, Fraser DF (1987) Habitat selection under predation hazard: test of a model with foraging minnows. Ecology 68:1856-1862

Grüebler MU, Maef-Daenzer B (2008) Postfledging parental effort in barn swallows: evidence for a trade-off in the allocation of time between broods. Anim Behav 75:1877-1884

Holt SA, Kitting CL, Arnold CR (1983) Distribution of young red drum (Sciaenops ocellatus) among different seagrass meadows. Trans Am Fish Soc 112:267-271

Houston AI, McNamara JM, Hutchinson JMC (1993) General results concerning the trade-off between gaining energy and avoiding predation. Philos Trans R Soc Lond B Biol Sci 341:375-397

Huntley ME, Lopez MDG (1992) Temperature-dependent production of marine copepods: a global synthesis. Am Nat 140:201-242

Ims RA (1990) On the adaptive value of reproductive synchrony as a predator-swamping strategy. Am Nat 136: 485-498

Jonsson B, Jonsson N, Hindar K, Northcote TG, Engen S (2008) Asymmetric competition drives lake use of coexisting salmonids. Oecologia 157:553-560

Jordan F, Bartolini M, Nelson C, Patterson PE, Soulen HL (1996) Risk of predation affects habitat selection by the pinfish Lagodon rhomboides (Linnaeus). J Exp Mar Biol Ecol 208:45-56

Kelly D (1994) The evolutionary ecology of mast seeding. Trends Ecol Evol 9:465-470

Kokko H (1999) Competition for early arrival in migratory birds. J Anim Ecol 68:940-950

Letcher BH, Rice JA, Crowder LB, Rose KA (1996) Variability in survival of larval fish: disentangling components 
with a generalized individual-based model. Can J Fish Aquat Sci 53:787-801

Levin PS, Stunz GW (2005) Habitat triage for exploited fishes: Can we identify essential 'Essential Fish Habitat?' Estuar Coast Shelf Sci 64:70-78

Milinski M, Boltshauser P, Büchi L, Buchwalder T and others (1995) Competition for food in swans: an experimental test of the truncated phenotype distribution. J Anim Ecol 64:758-766

Murphy GI (1968) Pattern in life history and the environment. Am Nat 102:391-403

Nakayama S, Fuiman LA (2010) Body size and vigilance mediate asymmetric interference competition for food in fish larvae. Behav Ecol 21:708-713

Nakayama S, Ojanguren AF, Fuiman LA (2009) To fight, or not to fight: determinants and consequences of social behaviour in young red drum (Sciaenops ocellatus). Behaviour 146:815-830

Nakayama S, Ojanguren AF, Fuiman LA (2011) Processbased approach reveals directional effects of environmental effects on movement between habitats. J Anim Ecol 80:1299-1304

Orzack SH, Tuljapurkar S (1989) Population dynamics in variable environments. VII. The demography and evolution of iteroparity. Am Nat 133:901-923

Partridge L, Sibly R (1991) Constraints in the evolution of life histories. Philos Trans R Soc Lond B Biol Sci 332:3-13

Pérez-Domínguez R, Holt SA, Holt GJ (2006) Environmental variability in seagrass meadows: effects of nursery environment cycles on growth and survival in larval red drum Sciaenops ocellatus. Mar Ecol Prog Ser 321:41-53

Persson L (1985) Asymmetrical competition: Are larger animals competitively superior? Am Nat 126:261-266

Peters KM, McMichael RH (1987) Early life history of the red drum, Sciaenops ocellatus (Pisces: Sciaenidae), in Tampa Bay, Florida. Estuaries 10:92-107

Philippi T, Seger J (1989) Hedging one's evolutionary bets, revisited. Trends Ecol Evol 4:41-44

Ricklefs RE, Wikelski M (2002) The physiology/life-history nexus. Trends Ecol Evol 17:462-468

Rooker JR, Holt SA (1997) Utilization of subtropical seagrass meadows by newly settled red drum Sciaenops ocellatus: patterns of distribution and growth. Mar Ecol Prog Ser

Editorial responsibility: Romuald Lipcius,

Gloucester Point, Virginia, USA
158:139-149

Rooker JR, Holt GJ, Holt SA (1998) Vulnerability of newly settled red drum (Sciaenops ocellatus) to predatory fish: Is early-life survival enhanced by seagrass meadows? Mar Biol 131:145-151

Rooker JR, Holt SA, Holt GJ, Fuiman LA (1999) Spatial and temporal variability in growth, mortality, and recruitment potential of postsettlement red drum, Sciaenops ocellatus, in a subtropical estuary. Fish Bull 97:581-590

Saucier MH, Baltz DM (1993) Spawning site selection by spotted seatrout, Cynoscion nebulosus, and black drum, Pogonias cromis, in Louisiana. Environ Biol Fishes 36: 257-272

Schaffer WM (1974) Optimal reproductive effort in fluctuating environments. Am Nat 108:783-790

Scheffer M, Baveco JM, DeAngelis DL, Rose KA, van Nes EH (1995) Super-individuals a simple solution for modelling large populations on an individual basis. Ecol Model 80:161-170

Sibly RM (1983) Optimal group size is unstable. Anim Behav 31:947-948

Soto MA, Holt GJ, Holt SA, Rooker J (1998) Food habits and dietary overlap of newly settled red drum (Sciaenops ocellatus) and Atlantic croaker (Micropogonias undulatus) from Texas seagrass meadows. Gulf Res Rep 10:41-55

Sutherland WJ, Parker GA (1985) Distribution of unequal competitors. In: Sibly RM, Smith RH (eds) Behavioural ecology: ecological consequences of adaptive behaviour. 25th Symp Br Ecol Soc. Blackwell Scientific, Oxford, p 255-274

van der Meer J (1997) The ideal free distribution when predators differ in competitive abilities. Oikos 80:301-310

Verhulst S, Tinbergen JM, Daan S (1997) Multiple breeding in the great tit. A trade-off between successive reproductive attempts? Funct Ecol 11:714-722

Werner EE, Hall DJ (1976) Niche shifts in sunfishes: experimental evidence and significance. Science 191:404-406

Wilbur HM, Rudolf VHW (2006) Life-history evolution in uncertain environments: bet hedging in time. Am Nat 168:398-411

Wilson CA, Nieland DL (1994) Reproductive biology of red drum, Sciaenops ocellatus, from the neritic waters of the northern Gulf of Mexico. Fish Bull 92:841-850

Submitted: March 30, 2011; Accepted: September 2, 2011

Proofs received from author(s): November 3, 2011 